\title{
Pálinkavásárlási szempontok vizsgálata conjoint-elemzés segítségével
}

\author{
Mucha Lászlól - Oravecz Titanilla² - Totth Gedeon² \\ 'Szent István Egyetem - ${ }^{2}$ Budapesti Gazdasági Egyetem
}

\section{A TANULMÁNY CÉLJA}

A kutatás középpontjában a pálinka három terméktulajdonságának (ár, eredet, gyümölcs) fontossága, szintjeinek hasznossága, illetve az ezek alapján kialakuló fogyasztói szegmensek vizsgálata áll.

\begin{abstract}
ALKALMAZOTT MÓDSZERTAN
Kutatási célunk megvalósítása érdekében értékelésen alapuló conjoint elemzést alkalmaztunk, melyben a házi illetve bolti eredetủ pálinkák (párlatok) három különböző gyümölcsfajból készült változatának a fogyasztói értékelését vizsgáltuk 626 fős mintán, amely 3 szempontra (nem, korcsoport, régió) megegyezik a 18 év feletti magyarországi lakosság összetételével. A hasznossági értékekből a fogyasztói csoportok szegmentálásához klaszteranalízist végeztünk.
\end{abstract}

\section{LEGFONTOSABB EREDMÉNYEK}

A pálinkavásárlás esetében az ár befolyásolta leginkább a vásárlási döntést, melyet a felhasznált gyümölcs, majd az eredet követett. A házi párlat, illetve a bolti pálinka közötti nagy árkülönbség miatt a fogyasztó az ár kiválasztásával egyúttal az eredetről is dönt. A vásárlás célja egyértelmúen determinálja az ár, a gyümölcs, és az eredet vásárlásban betöltött szerepét. A hazai termékek előtérbe helyezését jelentő fogyasztói etnocentrizmus jelensége nem befolyásolta a házi, illetve bolti eredet fogyasztók által megítélt hasznossági szintjét.

\section{GYAKORLATI JAVASLATOK}

A jogszabályi környezet, valamint a házi párlat egyértelmú preferáltsága nehéz helyzetbe hozza a kereskedelmi pálinkák előállítóit, ezért szükséges a fogyasztói döntések alapos megismerése, a conjoint-elemzés pedig lehetővé teszi ennek a vásárlási helyzetnek a szimulációját. A pálinkavásárlás során a fogyasztók nem egyértelmúen az olcsóbb terméket preferálják. Vizsgálatunk rávilágított, hogy pálinkavásárlásnál az olcsóbb ár nem feltétlenül jelent magasabb preferenciát, a fogyasztói döntés ennél sokrétübb. Kutatásunk is megerősítette a házi párlatok előnyben részesítését, melyet a kedvező imázs, valamint a bolti pálinka, és a házi párlat közötti jelentős árkülönbség egyaránt eredményez. A kialakult helyzet miatt a kereskedelmi pálinkák készítői új, és eredményes marketingkommunikációs stratégia kidolgozására kényszerülnek. A célcsoportok pontos behatárolása, valamint az ajándékozási céllal történő vásárlás erösítése növelheti a kereskedelmi pálinka gyártóinak versenyképességét. Ehhez mindenképpen olyan további kutatások lefolytatását javasoljuk, amelyek segítik azon fogyasztók behatárolását, akiknek a magasabb ár nagyobb hasznosságot jelent, megfelelő anyagi helyzettel rendelkeznek, városban laknak, és rövid ital vásárláskor a presztízs fontos döntési szempont számukra. Ezen vizsgálatok elvégzéséhez a conjoint-analízis módszerét alkalmasnak tartjuk.

Kulcsszavak: conjoint-analízis, fogyasztói etnocentrizmus, pálinka, preferenciák

Köszönetnyilvánitás: A publikáció az Innovációs és Technológiai Minisztérium ÚNKP-19-3-SZIE-48 kódszámú Új Nemzeti Kiválóság Programjának szakmai támogatásával készült.

DOI: 10.15170/MM.2020.54.02.04 


\section{BEVEZETÉS INTRODUCTION}

\section{Pálinka \\ Pálinka}

Az Európai Parlament és a Tanács által jegyzett, 110/2008/EK rendelet értelmében uniós oltalomban részesül a „Pálinka” és „Törkölypálinka” megjelölés, vagyis a pálinka elnevezés kizárólag Magyarországon (illetve barackpárlatok esetében további 4 osztrák tartományban) használható. A pálinka készítéséről, névhasználatáról a 2008. évi LXXIII. törvény fogalmaz meg további eloírásokat.

A fogyasztók tévesen a Pálinkatörvény elöírásainak nem megfelelő pálinkajellegü italokat is pálinkaként azonosítják, melyet számtalan hazai kutatás megerősített. Ahogyan Szegedyné és tsai (2017) rámutatnak, az emberek többségének még mindig a házi párlat jelenti az igazi pálinkát. 2017-es, a pálinkafogyasztásról készült átfogó tanulmányukban megemlítik, hogy válaszadóik a technikai és technológiai szempontból kicsit vagy teljesen hibás terméket is igazi pálinkaként definiálták.

Vizsgálatunk célja a vásárlási preferencia, és a fogyasztók által észlelt hasznosság feltárása volt. Ahogyan Varian (2010) rámutat, a fogyasztó rangsorolja szükségleteit, történjen ez tudatosan, vagy akár ösztönös módon.

A pálinka kiskereskedelmi forgalmát viszszavetette az otthoni pálinkafózés engedélyezése, a Pálinka Nemzeti Tanács szerint a helyzet az ágazat sikerességét veszélyezteti, valamint felhívják a figyelmet a magánfőzés okozta feketekereskedelem problémájára is (https://www.palinkanemzetitanacs.hu/hu/aktualitasok/42).

A conjoint elemzésben vizsgált termék attribútumokat, és azok szintjeit számos hazai kutatás (Fodor és tsai 2011, Szegedyné és tsai 2017, Totth 2009, Totth és tsai 2017) eredményét figyelembe véve alakítottuk ki, a kiválasztott terméktulajdonságok az eredet, ár, és a gyümölcs. Ahogyan Ailawadi et al. (2001) rámutat, az ár az egyik legfontosabb minőségindikátor, véleményünk szerint a pálinka esetében az olcsóbb ár magasabb preferenciát jelent. Ofir (2004) szerint az árérzékeny fogyasztók elözetes felméréseket végeznek az üzletek kínálatairól, majd az elérhető legalacsonyabb áron vásárolják meg az adott terméket.

\section{FOGYASZTÓI ETNOCENTRIZMUS CONSUMER ETHNOCENTRISM}

Sumner (1906) etnocentrizmus fogalma alapján Shimp és Sharma (1987) definiálta a külföldi áruk beszerzését elutasító fogyasztói magatartást. Miskolczi (2011) szerint a „magyar” mint termékjelző alkalmazása napjainkban divatos marketingeszközzé vált Magyarországon. A hazai empirikus kutatások (Fodor és tsai 2011, Szegedyné és tsai 2017, Totth 2009, Totth és tsai 2017) szerint a fogyasztók a házi párlatot tartják az igazi pálinkának, ezért vizsgáljuk a fogyasztói etnocentrizmus pálinkapreferenciában betöltött esetleges szerepét.

Domán (2007) szerint a borfogyasztásban az ízlésdivat, a sznobizmus, és a presztízs egyaránt szerepet játszik, több szerző (Hofmeister 2003, Kotler 2006, Törőcsik 2007) is megemlíti, hogy a fogyasztás presztízsjelző funkciót is betölthet. Kutatásunkban a presztízs hatását is vizsgáljuk.

\section{CONJOINT ELEMZÉS CONJOINT-ANALYSIS}

A fogyasztói preferenciák mérésére (Green et al. 2001; Gustafsson et al. 2003; Wittink et al. 1994), és a fogyasztói kompromisszumok elemzésére a marketing egyik legnépszerübb módszere a conjoint analízis. A conjoint elemzés gyakran használatos a fogyasztók fizetési hajlandóságának, és a vásárlási preferenciáinak megismerésére azokban az esetekben, amikor a fogyasztók különböző termékek között kénytelenek választani (Mahajan et al. 1982, Page \& Rosenbaum 1987). A szükségletek egyéni rangsorát preferenciaskálának nevezzük, azonban a preferencia nem azonos a tényleges választással, hívja fel a figyelmet Farkasné és Molnár (2006), ugyanis amikor a fogyasztó tényleges döntést hoz vásárlásának tárgyáról, saját belső értékrendjéből kiindulva figyelembe veszi a javak hasznos tulajdonságait, személyes pénzjövedelmét és természetesen az árakat.

Ahogyan Huertas-Garcia et al. (2014) rámutatnak, az ügyfelek igényeinek megértése, és az észlelt érték legfontosabb tényezőinek meghatározása érdekében a kutató közvetlenül megkérdezheti a fogyasztókat, vagy megpróbálhat valamilyen közvetett módszer, pl. kísérletezés útján következtetéseket levonni. Sattler és Hensel-Börner (2003) úgy gondolja, hogy a conjoint elemzés miközben növeli a valódi döntésekhez történő hasonlóságot, csökkenti a társadalmilag elfogadható válaszok gyűjtésének kockázatát. Malhotra (2005) 
szerint a módszer az egyes termékjellemzőket külön skáláknak (faktoroknak) tekinti, amelyek lehetséges konkrét értékei a faktorszintek.

A teljes profilú eljárásnál Malhotra (2005) szerint a márkák teljes vagy hiánytalan profiljait az összes jellemző különböző szintjeinek felhasználásával a kutatási tervben meghatározott módon készítik el. A teljes profilú eljárás esetében fontos a viszonylag kisszámú termék attribútum (conjoint-elemzésben faktor), és szint. Erre Balderjahn (1994), valamint Scipione (1994) is felhívta a figyelmet. Bernáth és Szabó (1997) szintén megerősítették, hogy 5-6 termékjellemző fölött jelentősen csökken az eredmények megbízhatósága. Szücs és tsai (2018) előre csomagolt szeletelt sajt, és chips vonatkozásában végeztek értékelésen alapuló, és choice-based conjoint-elemzést magyar, román, és spanyol fogyasztók megkérdezésével. Rámutatnak, hogy a choice-based módszerben a termék stimulusokat valamilyen szempont alapján történő választására használják, kihangsúlyozzák, hogy mindkettő módszernek megvannak a maga előnyei és hátrányai. $\mathrm{Az}$ ún. hibrid conjoint-elemzésben mindegyik válaszadó nagyszámú profilt értékel, mégis rendszerint csupán egyszerú részértékeket vagy föhatásmodellt becsülnek az interakciós hatások figyelembe vétele nélkül (Malhotra 2005).

\section{HIPOTÉZISEK HYPOTHESES}

H1 hipotézisünkben azt feltételezzük, hogy a pálinka három terméktulajdonsága (ár, eredet, gyümölcs) közül az árnak van a legnagyobb fontossága. H2 hipotézisünk szerint minél olcsóbb a pálinka, annál preferáltabb. A házi pálinka kedvező imázsa miatt úgy gondoljuk, hogy a fogyasztók által a második legnagyobb fontosságúnak ítélt termékjellemző az eredet, azaz „házi” vagy „bolti” (kereskedelmi főzdében elóállított) pálinkáról van szó (H3). (Habár az otthon, illetve a bérfözdékben készült termék nem nevezhető pálinkának, az előbbi termékekre mi is a házi pálinka kifejezést alkalmazzuk, már csak azért is, mert a köznyelvben így terjedt el, és a kérdezés során is a könnyebb érthetőség kedvéért ezt a megfogalmazást használtuk.) H4 hipotézisünk szerint a házi pálinkának az idős vidékiek nagyobb hasznosságot tulajdonítanak. Véleményünk szerint a fogyasztói etnocentrizmus befolyásolja a házi pálinka preferenciáját (H5).

\section{ANYAG ÉS MÓDSZER MATHERIAL AND METHOD}

Az adatgyüjtés kérdőívezéssel történt, melyet kvótás mintavétel módszerével személyesen kérdeztünk le 2019 őszén. A válaszadók a megkérdezést megelőző három hónapban pálinkát fogyasztó 18 év feletti felnőtt magyar lakosságból kerültek ki (1. táblázat). A minta összetétele a 2019-es országos adatok alapján (KSH 2019) nem, korcsoport, és régió szempontjából megegyezik a 18 év feletti magyarországi lakosság összetételével. Ahogyan Malhotra (2005) rámutat, a nem véletlen minták - mint például a kvótás mintavétel - jó becslést adhatnak a sokasági jellemzőkkel kapcsolatosan, a hagyományos véletlen mintavételhez közeli eredményekhez juthatunk. A minta demográfiai megoszlását, és a reprezentativitásra vonatkozó statisztikai próbákat az 1. táblázat tartalmazza. Az adatok elemzése SPSS 25.0, és Excel segítségével történt.

Vizsgálatunkban a viszonylag kisszámú termék attribútum miatt értékelésen alapuló teljes profilú conjoint-analízist alkalmaztunk. Moskowitz et al. (2009) szerint a teljes körü conjoint analízisben a fogyasztók kifejezik a vásárlási hajlandóságukat az egyes termékváltozatokról, amely lehetővé teszi a termékjellemzőknek a fogyasztói megítélés szerinti relatív jelentőségének becslését mind aggregált, mind egyéni szinten. 


\section{1. táblázat: A minta szocio-demográfiai megoszlása (\%; fó) \\ Table 1. Demographic Data of Respondents}

\begin{tabular}{|l|l|c|c|}
\hline \multicolumn{1}{|l|}{ Demográfiai csoportok } & KSH 2019 (\%) & Saját minta (fö) \\
\hline \multirow{4}{*}{ Nem } & Férfi & 47,85 & 300 \\
\cline { 2 - 4 } & Nö & 52,15 & 326 \\
\hline \multirow{5}{*}{ Korcsoport } & $18-24$ éves & 9,42 & 67 \\
\cline { 2 - 4 } & $25-34$ éves & 15,4 & 109 \\
\cline { 2 - 4 } & $35-44$ éves & 19,08 & 117 \\
\cline { 2 - 4 } & $45-54$ éves & 16,84 & 106 \\
\cline { 2 - 4 } & $55-64$ éves & 15,82 & 99 \\
\cline { 2 - 4 } & 65 év felett & 23,44 & 128 \\
\hline \multirow{5}{*}{ Régió } & Budapest & 17,93 & 114 \\
\cline { 2 - 4 } & Pest & 13,09 & 82 \\
\cline { 2 - 4 } & Észak-Magyarország & 11,53 & 72 \\
\cline { 2 - 4 } & Észak-Alföld & 14,85 & 93 \\
\cline { 2 - 4 } & Dél-Alföld & 12,66 & 79 \\
\cline { 2 - 4 } & Közép-Dunántúl & 10,83 & 68 \\
\cline { 2 - 4 } & Nyugat-Dunántúl & 10,12 & 61 \\
\cline { 2 - 4 } & Dél-Dunántúl & 9,00 & 57 \\
\hline
\end{tabular}

Megjegyzés: Reprezentativitás: nem (observed prop. $=0,5208$; test prop. $=0,5215 ; p=0,501$ ); korcsoport $\left[\chi^{2}(d f=5, N=626)=5,334, p=0,376\right]$; régió $\left[\chi^{2}(d f=7, N=626)=0,115, p=1,000\right]$

Forrás: saját szerkesztés

A conjoint elemzésben vizsgált három faktorhoz (eredet, ár, gyümölcs) 2-3-3 szintet rendeltünk, amely összesen 18 különböző kártya kialakítását eredményezte. A teljes profil megközelítésnél a stimulusprofilok száma csökkenthető a redukált faktoriális elrendezéssel. A kártyák kialakításakor az ún. ortogonális elrendezést alkalmaztuk, amely Malhotra (2005) szerint a redukált elrendezés speciális fajtája, alkalmazása lehetővé teszi az összes föhatás hatékony becslését.-

A hasznossági értékekből a homogén fogyasztói csoportok azonosításához klaszteranalízist alkalmaztunk. Elöször hierarchikus technikával (Ward módszer) megállapítottuk a klaszterek ideális számát, valamint a középpontokat, majd nem hierarchikus módszerrel (K-Means eljárás) csoportosítottunk a hierarchikus módszerből származó klaszterközéppontok alapján.

Az etnocentrizmus mérésére a Shimp és Sharma (1987) által kidolgozott 17 elemủ állítás-listát (CETSCALE) alkalmaztuk. Sharma (2015) szerint módszerük bizonyítottan képes megjósolni a vásárlási szándékokat és a tényleges vásárlási viselkedést a hazai és a külföldi termékek esetében a világ számos országában, különböző termékkategóriákban. Jaffe és Nebenzahl (2001) véleménye szerint azok a termékek, amelyek alapvetőek egy ország gazdasága számára (mint pl. az élelmiszer) erősebb etnocentrikus viselkedést generálnak.

\section{EREDMÉNYEK RESULTS}

A megkérdezettek által rangsorolt 9 kártyára elvégzett conjoint-elemzés szignifikánsnak, és megfelelő erősségünek bizonyult (Pearson's $\mathrm{R}=0,737$, $\mathrm{p}=0,012$; Kendall's tau $=0,556, \mathrm{p}=0,019$ ).

A faktorok relatív fontossági értékeit, és részhasznosságait a 2. táblázatban foglaltuk össze, hasonlóan Szabó $(2006,99)$ doktori disszertációjában alkalmazott megoldásához. 
2. táblázat: Az egyes termék attribútumok relatív fontosság, és hasznosság értékei Table 2. The relative importance and utility values of each pálinka attribute

\begin{tabular}{|c|c|c|c|}
\hline Faktor & Faktor relatív fontossága & Faktor szintek & Részhasznosságok \\
\hline \multirow{3}{*}{ Ár } & \multirow{3}{*}{$40 \%$} & $6000 \mathrm{Ft}$ & 0,370 \\
\hline & & $3000 \mathrm{Ft}$ & $-0,014$ \\
\hline & & $9000 \mathrm{Ft}$ & $-0,355$ \\
\hline \multirow{3}{*}{ Gyümölcs } & \multirow{3}{*}{$37,9 \%$} & Barack & 0,247 \\
\hline & & Szilva & 0,057 \\
\hline & & Körte & $-0,304$ \\
\hline \multirow{2}{*}{ Eredet } & \multirow{2}{*}{$22.1 \%$} & Házi & 0,085 \\
\hline & & Bolti & $-0,085$ \\
\hline
\end{tabular}

Forrás: saját szerkesztés

A conjoint elemzés során az ár bizonyult a legnagyobb relatív fontosságú terméktulajdonságnak (40\%), ezt követte a gyümölcsfaj $37,9 \%$-kal, végül az eredet 22,1\%-os értékkel. H1 hipotézisünkben azt feltételeztük, hogy a három terméktulajdonság közül az árnak van a legfontosabb szerepe, melyet a conjoint-elemzés megerősített. A kereskedelmi forgalomban kapható pálinkák fél litere minimum 5-6000 Ft-ba kerül (https://palinka.arukereso.hu/), a házi párlatok nem hivatalos ára 3-4000 Ft literenként. Az ár szerepe termékfüggö. A második legfontosabbnak ítélt termékjellemzőnek az eredetet feltételeztük (H3), melyet a kutatás nem támasztott alá. A részhasznosságokat vizsgálva megállapítható, hogy az ár faktorban a 6000 Ft-os literenkénti árnak tulajdonították a megkérdezettek a legnagyobb hasznosságot, melyet a $3000 \mathrm{Ft}$, majd a 9000 Ft-os hasznosság értékek követtek. Gyümölcsfaj szempontjából leginkább a barack preferált, második a szilva, a három gyümölcs közül a legkisebb hasznosságot a körtének tulajdonították a megkérdezettek. A vizsgálatban a házi eredet magasabb hasznosság értéket kapott, mint a bolti.

A faktor szintek között szignifikáns különbség van. Mivel a conjoint-elemzés során az SPSS statisztikai szoftver által minden megkérdezettre kiszámolt hasznosság értékek nem követték a normál eloszlást, ezért t-próbákat, és ANOVA-t nem alkalmazhattunk a vizsgálat során, csak azok nemparaméteres megfelelőit. A házi eredet részhasznossága szignifikánsan magasabb, mint a bolti eredeté (páros mintás Wilcoxon-próba: $\mathrm{Z}=-2.138$, $\mathrm{p}=0,033)$. A 6000 Ft-os hasznossági értékek szignifikánsan magasabbak, mint a $3000 \mathrm{Ft}$, ami szignifikánsan magasabb, mint a 9000 Ft hasznosság értékei. [Friedman próba: $\chi^{2}(\mathrm{df}=2, \mathrm{~N}=626)=42,663$, $\mathrm{p}<0,001]$. A barack hasznossági értékek szignifikánsan magasabbak, mint a szilva, ami szignifikánsan magasabb, mint a körte hasznosság értékei [Friedman próba: $\left.\chi^{2}(\mathrm{df}=2, \mathrm{~N}=626)=35,905, \mathrm{p}<0,001\right]$.

\section{Az ár szerepének vizsgálata Analysing the role of price}

H2 hipotézisünkben azt feltételeztük, hogy minél olcsóbb a pálinka, annál preferáltabb. A conjoint-elemzésben a 6000 Ft-os literenkénti ár kapta a legnagyobb részhasznosságot, mely $\mathrm{H} 2$ hipotézisünket nem támasztotta alá. Amennyiben a faktorszintek, és a preferenciák között lineáris kapcsolatot felételezünk, lehetőségünk van a vizsgálatot ezen feltétel megadásával lefolytatni. Ebben az esetben az az ún. reversals értékek adnak tételes visszajelzést arról, hogy a kapcsolat irányára tett feltételezésünk hol nem igazolódott be (Ketskeméty és tsai 2011). Az alacsonyabb ár, magasabb preferencia beállítással lefuttatott conjoint-elemzés ugyan az alapértelmezettnél rosszabb modellt eredményezett, azonban még így is nagyon fontos információkat tárt föl számunkra. A válaszadók 42\%-a számára a magasabb ár kedvezőbb hasznosságot jelentett.

A demográfiai összetételt vizsgálva megállapítottuk, hogy a magasabb ár kedvezőbb preferencia csoportba tartozó válaszadók 11,7\%-a 18-24 éves, 19,2\%-a 25-34 éves, 21,5\%-a 35-44 éves 14,3\%-a 45-54 éves, 13,6\%-a 55-64 éves, 19,6\%-a 65 év feletti. A legnagyobb arányt képviselő 35-44 éves válaszadók 48,7\%-ának jelentett a drágább termék 
nagyobb hasznosságot. Az idősebb válaszadók árérzékenységét mutatja, hogy az 55-64 éves válaszadók 63,6\%-a tartozik abba a csoportba, melynek az alacsonyabb ár kedvezőbb preferenciát jelent. A magasabb ár kedvezőbb preferencia csoportba tartozó válaszadók 5,3\%-a 8 általánossal, vagy kevesebbel, 14,3\%-a szakmunkásképzővel, 43,8\%-a középiskolai végzettséggel, 36,6\%-a felsőfokú végzettséggel rendelkezik. Az ebbe a csoportba tartozó válaszadók 18,5\%-a lakik Budapesten, 15,5\%-a megyeszékhelyen, 46,8\%-a városban, 7,5\%-a községben, 11,7\%-a falun. Anyagi helyzet szempontjából 0,8\%-ának még a legszükségesebb dolgokra sincsen elég pénze. 5,7\%-ának nagyon sok dolog megvásárlásáról le kell mondania, 38,1\%ának elegendő pénze van a mindennapi élethez, de nem engedhet meg magának nagyobb kiadásokat, 47,9\%-ának elegendő pénze van a kiadásaira, és még megtakarítani is tud, 7,5\%-a pedig jómódú.

A conjoint-elemzésben élhetünk olyan elöfeltevéssel, miszerint egy változónak létezik egy úgynevezett ideális szintje, amelynél a preferencia maximális, és az ideálistól bármelyik irányban távolodva a preferencia csökken (Ketskeméty és tsai 2011). $\mathrm{Az}$ erre a beállításra lefuttatott conjoint-analízis eredménye (Pearson's R=0,737, p=0,012; Kendall's tau $=0,556, p=0,019)$ szerint ez az ideális érték 5539 Ft-os literenkénti árat jelent.

\section{Klaszteranalízis Cluster analysis}

A klasztereket, és hasznosságértékeiket a 3. táblázat tartalmazza. Az 1. számú klaszterbe 340 fó tartozik, ők a 6000 Ft-os literenkénti árat, a bolti eredetet, és a barack gyümölcsöt preferálják, öket „bolti pálinka kedvelö” csoportnak neveztük el. A 2. számú klaszterbe 286 fö tartozik, ők a 3000 Ft-os literenkénti árat, a házi eredetet, és a szilva gyümölcsöt tartják a leghasznosabbak, ezen válaszadók alkotják a „házi pálinka kedvelő” csoportot. A demográfiai háttérváltozókat vizsgálva megállapítottuk, hogy a két klaszter összetétele között nincsen számottevő eltérés nem, és korcsoport tekintetében. A ,bolti pálinka kedvelő” klaszterbe tartozó válaszadók 5,0\%-a 8 általánossal, vagy kevesebbel, 16,2\%-a szakmunkásképzővel, 43,2\%-a középiskolai végzettséggel, 35,6\%-a felsőfokú végzettséggel rendelkezik. Az olcsóbb házi pálinkát preferáló klaszterbe tartozó válaszadók 4,2\%-a 8 általánossal, vagy kevesebbel, 16,1\%-a szakmunkásképzővel, 38,1\%-a középiskolai végzettséggel, 41,6\%-a felsőfokú végzettséggel rendelkezik. A házi pálinka népszerü termék az értelmisé- giek körében. Szignifikáns eredményeket kaptunk lakhely tekintetében, a „bolti pálinka kedvelö" klaszterbe tartozó válaszadók 15,3\%-a lakik Budapesten, 14,4\%-a megyeszékhelyen, 49,7\%-a városban, 8,8\%-a községben, 11,8\%-a falun. A „házi pálinka kedvelő" klaszterbe tartozó válaszadók 22,7\%-a lakik Budapesten, 19,6\%-a megyeszékhelyen, 40,9\%-a városban, 7,7\%-a községben, 9,1\%-a falun. A legszegényebb válaszadók $28,6 \%$-a tartozik a „bolti pálinka kedvelő” klaszterbe, 71,4\%-uk pedig a házi pálinkát preferáló klaszterbe. A megtakarítani tudó válaszadók 56,5\%-a tartozik a „,bolti pálinka kedvelő" csoportba, 43,5\%-uk pedig a házi pálinkát előnyben részesítő klaszterbe.

A klasztereket a fogyasztói etnocentrizmus szempontjából is megvizsgáltuk. Válaszadóinkat az etnocentrikus fogyasztói magatartást vizsgáló 17 elemü állítás-listára adott válaszaik alapján három csoportra osztottuk (kevésbé etnocentrikus, közepesen etnocentrikus, etnocentrikus). A „bolti pálinka kedvelö" klaszterbe tartozó válaszadók 34,4\%-a tartozik a kevésbé etnocentrikus csoportba, 30,3\%-a a közepesen etnocentrikus csoportba, és 35,3\%-a az etnocentrikus csoportba. A házi pálinkát preferáló klaszterbe tartozó válaszadók 32,2\%-a tartozik a kevésbé etnocentrikus csoportba, 36,7\%-a a közepesen etnocentrikus csoportba, és $31,1 \%$-a az etnocentrikus csoportba. H5 hipotézisünkben összefüggést feltételeztünk a házi pálinka preferáltsága, és a fogyasztói etnocentrizmus jelensége között. A klasztereket vizsgálva megállapítottuk, hogy az etnocentrikus fogyasztói magatartás szempontjából nincsen szignifikáns különbség a 2 klaszter válaszadói között. A pálinka tradicionális magyar termék, kutatásunk értelmében a házi pálinka bolti pálinkához viszonyított preferáltságát a fogyasztói etnocentrizmus nem befolyásolja. 


\section{3. táblázat: Az értékelésen alapuló conjoint-elemzés alapján}

kialakított klaszterek és azok hasznosság értékei

Table 3. Clusters formed on the basis of evaluation-based conjoint analysis and their utility values

\begin{tabular}{|c|c|c|}
\hline & 1. klaszter & 2. klaszter \\
\hline $3000 \mathrm{Ft}$ & -.82 & .95 \\
\hline $6000 \mathrm{Ft}$ & 1.34 & -.78 \\
\hline $9000 \mathrm{Ft}$ & -.51 & -.17 \\
\hline Házi & .02 & .16 \\
\hline Bolti & -.02 & -.16 \\
\hline Szilva & -.12 & .27 \\
\hline Körte & -.15 & -.48 \\
\hline Barack & .28 & .21 \\
\hline
\end{tabular}

Forrás: saját szerkesztés

\section{Az eredet szerepének vizsgálata Analysing the role of the orgin}

A házi, illetve bolti eredetủ pálinka közötti preferenciakülönbség minél alaposabb megismeréséhez a conjoint-elemzés során kapott hasznosságértékekből a válaszadókból három csoportot képeztünk: a házi eredetnek nagyobb hasznosságot tulajdonító; a bolti eredetnek nagyobb hasznosságot tulajdonító; a két eredetnek egyforma hasznosságot tulajdonító válaszadókat. A férfiak inkább tartoznak a házi eredetet nagyobb hasznosságúnak ítélő csoportba, 49,0\%-uk a házi pálinkát ítélte meg hasznosabbnak, $39,0 \%$-uk pedig a bolti pálinkát (12,0\%-a egyforma hasznosságúnak ítélte meg). A nők esetében nem volt különbség az értékek között. H4 hipotézisünk szerint a házi pálinkának az idős vidékiek nagyobb hasznosságot tulajdonítanak. A 35 évesnél fiatalabb válaszadóink nagyobb hasznosságot tulajdonítottak a bolti eredetnek. A preferencia a 35 évesnél idősebb megkérdezettek esetében változott meg. Az 55-64 éves válaszadók 49,5\%-a a házi eredetet ítélte meg hasznosabbnak, $37,4 \%$-uk pedig a boltit. $\mathrm{Az} 65$ év feletti válaszadók esetében ez az arány 48,4\%-illetve 43,8\% volt. Lakhely szempontjából a községben élő válaszadók 50\%-a tulajdonított a házi eredetnek nagyobb hasznosságot, 42,3\%-a a boltinak, 7,7\%-a egyformának. A falusi válaszadók 47,0\%-a tulajdonított a házi eredetnek nagyobb hasznosságot, 39,4\%-a a boltinak, 13,6\%-a egyformának. A Budapesten, a megyeszékhelyen, illetve a városban élő válaszadók között nem találtunk különbséget. H4 hipotézisünket kutatási eredményeink megerösítették.
A megkérdezettek vásárlási szempontjait vizsgálva szignifikáns összefüggés $\left[\chi^{2}(\mathrm{df}=4, \mathrm{~N}=626)\right.$ $=11,886, p=0,018 ; \gamma=0,104]$ van a presztízs, mint vásárlási szempont, valamint az eredet hasznosságértékei között. Azon válaszadók, akiknek a presztízs fontos rövid ital vásárlási szempont, 15,1\%-a egyforma hasznosságúnak ítélte meg a házi, illetve a bolti pálinkát, 37,7\%-uk a házi pálinkát ítélte meg hasznosabbnak, 47,3\%-uk pedig a bolti pálinkát. A fogyasztói etnocentrizmus szerepét vizsgálva akárcsak a klaszteranalízissel létrehozott csoportok esetében - itt sem találtunk összefüggést.

\section{A KUTATÁS KORLÁTAI LIMITATIONS OF THE RESEARCH}

Az árral kapcsolatos vizsgálat eredményeit a kérdőív, és ezáltal a kutatás lehatároltsága, valamint a fogyasztói magatartás egyaránt magyarázza. Kérdőívünkben válaszadóinkat a kártyák rangsorolására kértük a vásárlás céljának meghatározása nélkül, mely lehetőséget adott a kitöltők számára a kérdés különböző értelmezésére. További magyarázatot adhat az eredményekre, hogy a fogyasztók jelentős részének - föként, ha nem tájékozottak az adott termékkel kapcsolatosan - az ár a legfontosabb minőségindikátor. Korábbi kutatásokból egyértelmüen kiderül, hogy ajándékba lényegesen magasabb áron választanak a hazai vásárlók pálinkát, mint saját fogyasztásra. 


\section{KÖVETKEZTETÉSEK, JAVASLATOK CONCLUSIONS AND PROPOSALS}

Az elmúlt évtizedekben a kereskedelmi pálinkafőzdék sokat tettek azért, hogy a pálinkáról az értékes magyar ital képe alakuljon ki a fogyasztókban. Azonban a jogszabályi környezet megváltozása, a házi fözés engedélyezése, a házi párlatok kedvező imázsa, a bérfözdék termelésének a növekedése nehéz helyzetbe hozta a kereskedelmi fözdéket, a bolti pálinka gyártóit. A magánfözésben elóállított párlat valódi nagyságára csak becslések vannak. Kutatásunkban conjoint-elemzés segítségével vizsgáltuk a különböző terméktulajdonságok fogyasztók által észlelt fontosságát. Szücs és tsai (2018) vizsgálatában az általuk meghatározott 3 faktor (tartósítószer, csomagoló gáz, ár) relatív fontosság értékei közül az ár bizonyult a legkevésbé fontosnak. Pálinkavásárlásnál az ár bizonyult a legnagyobb relatív fontosságú termék tulajdonságnak (40\%) ezt követte a gyümölcsfaj 37,9\%-kal, végül az eredet $22,1 \%$-os értékkel. A fogyasztó az ár meghatározásával egyidejüleg dönt az eredetről is. A bolti pálinka, és a házi párlat közötti jelentős árkülönbség, valamint a házi párlatok kedveltsége, divatja miatt a kereskedelmi pálinkák készítői megfelelő marketingkommunikációs stratégia kidolgozására kényszerülnek. Kutatásunk rávilágított arra, hogy pálinkavásárlásnál az olcsóbb ár nem feltétlenül jelent magasabb preferenciát, a célcsoportok pontos behatárolása, valamint az ajándékozási céllal történő vásárlás erősitése növelheti a kereskedelmi pálinka gyártóinak versenyképességét. Kutatásunk megerősítette több szerző megállapítását, miszerint a fogyasztás presztízsjelző funkciót is betölthet, ez a kapcsolat a bolti pálinka esetében volt kimutatható. A pálinka tradicionális magyar termék, kutatásunk értelmében a házi pálinka bolti pálinkához viszonyított preferáltságát a fogyasztói etnocentrizmus nem befolyásolja.

\section{HIVATKOZÁSOK REFERENCES}

2008. évi LXXIII. törvény a pálinkáról, a törkölypálinkáról és a Pálinka Nemzeti Tanácsról: https://net.jogtar.hu/jogszabaly?docid $=a 0800073 . t v$ (letöltve: 2020.03 .11 .)

Ailawadi, K, L., Neslin, S. A. and Gedenk, K. (2001), "Pursuing the Value-Conscious Consumer: Store Brands versus National Brand Promotions", Journal of Marketing, 65(1), 71-89 DOI: $10.1509 / \mathrm{jmkg} .65 .1 .71 .18132$

Az Európai Parlament és a Tanács 110/2008/EK rendelete: https://eur-lex.europa.eu/legal-content/ HU/TXT/HTML/?uri=CELEX:32008R0110\&from=HU (letöltve: 2020.03.10.)

Balderjahn, I. (1994), "Der Einsatz der Conjoint-Analyse zur emprischen Bestimmung von Preisreponse-funktionen", Marketing ZFP, 16(1), 12-19 DOI: 10.1007/978-3-8350-90064_3

Bernáth A., Szabó T. (1997), „Új lehetőségek a marketing-információelemzésben: A conjointanalízis", Marketing \& Menedzsment, 31(4), $539-46$

Domán Sz. (2007), „Jobban ízlik-e a drágább bor? A bor minősége és ára összefüggéseinek vizsgálata vaktesztek segítségével”, Marketing \& Menedzsment, 41(4-5), 64-67

Farkasné F. M., Molnár J. (2006), Mikroökonómia, Budapest, Szaktudás Kiadó Ház

Fodor M., Hlédik E., Totth G. (2011), „Fogyasztói vélemények és preferenciák a pálinka piacán". Élelmiszer, Táplálkozás és Marketing, 8(1-2), 41-47

Green, P. E, Krieger, A. M. and Wind, Y. (2001), "Thirty years of conjoint analysis: reflections and prospects", Interfaces, 31(3), 56-73 DOI: 10.1287/inte.31.3s.56.9676

Gustafsson, A., Herrman, A. and Huber, F. (2003), Conjoint Measurement. Methods and Applications, Berlin, Springer-Verlag

Hofmeister T. Á. (2003), Fogyasztói magatartás, Budapest, Aula Kiadó

https://palinka.arukereso.hu/ (letöltve: 2020.03.01.)

https://www.ksh.hu/docs/hun/xstadat/xstadat eves/i_wdsd003c.html

https://www.ksh.hu/docs/hun/xstadat/xstadat eves/i_wdsd004c.html

https://www.palinkanemzetitanacs.hu/hu/aktualitasok/42 (letöltve: 2019.10.20.)

Huertas-Garcia, R., Laguna García, M. and Consolación, C. (2014), "Conjoint analysis of tourist choice of hotel attributes presented in travel 
agent brochures", International Journal of Tourism Research, 16(1), 65-75 DOI: 10.1002/ jtr. 1899

Jaffe, E. D. and Nebenzahl, I. D. (2001), National Image and Competitive Advantage: The Theory and Practice of Country-of-Origin Effect, Copenhagen Business School Press, Copenhagen

Ketskeméty L., Izsó L., Könyves T. E. (2011), Bevezetés az IBM SPSS Statistics programrendszerbe, Budapest, Artéria Stúdió

Kotler, P. (2006), Marketing menedzsment, Budapest, Akadémiai Kiadó

KSH (2019), A lakónépesség korcsoport szerint, január 1. (2001-)

Mahajan, V., Green, P. E. and Goldberg, S. M. (1982), "A conjoint model for measuring selfand cross-price/demand relationships", Journal of Marketing Research, 19, 334-342 DOI: $10.2307 / 3151567$

Malhotra, N. K. (2005), Marketingkutatás, Budapest, Akadémiai Kiadó

Miskolczi, B. P. (2011), „Termékek „magyarként” való reklámozásának jogi kérdései”, Versenytükör, 2, 24-34

Moskowitz, H. R., Reisner, M., Lawlor, J. B. and Deliza, R. (2009), Packaging research in food product design and development, John Wiley \& Sons - Wiley-Blackwell, DOI: 10.1002/9781444319330.advert

Ofir, C. (2004), "Reexamining Latitude of Price Acceptability and Price Thresolds: Predicting Basic Consumer Reaction to Price", Journal of Consumer Research, 30(4), 612-621 DOI: $10.1086 / 380293$

Page, A. L. and Rosenbaum, H. F. (1987), "Redesigning product lines with conjoint analysis: how sunbeam does it", Journal of Product Innovation Management, 4, 120-137 DOI: 10.1111/1540-5885.420120

Sattler, H. and Hensel-Börner, S. (2003), "A comparison of conjoint measurement with self-explicated approaches", in: Gustafsson, A., Herrmann, A. and Huber, F. (Eds.), Conjoint measurement: Methods and applications, Berlin, Springer, 147-159 DOI: 10.1007/978-3540-71404-0 4

Scipione, P. A. (1994), A piackutatás gyakorlata, Budapest, Springer Hungarica

Sharma, P. (2015), "Consumer ethnocentrism: Reconceptualization and cross-cultural validation", Journal of International Business Studies, 46, 381-389 DOI: 10.1057/jibs.2014.42

Shimp, T. A. and Sharma, S. (1987), "Consumer Ethnocentrism: Construction and Validation of the
CETSCALE," Journal of Marketing Research, 24(3), 280-289 DOI: 10.2307/3151638

Sumner, W. G. (1906), Folkways: A Study of the Sociological Importance of Usages, Manners, Customs, Mores, and Morals, Boston, Ginn and Company

Szabó E. (2006), Az eredet-és minőségjelzők alkalmazásának lehetőségei és feltételei a marketingkommunikációban, Doktori disszertáció, Budapesti Corvinus Egyetem

Szegedyné F. Á., Szakos D., Bódi B., Kasza Gy. (2017), „Pálinka, fogyasztói ismeretek, preferenciák, fogyasztói szokások, marketinglehetőségek", Gazdálkodás, 60(2), 158-170.

Szücs V., Szabó E., Tarcea M., Guerrero L., Bánáti D. (2018), „Élelmiszeripari adalékanyagok szerepe a vásárlási döntésekben conjoint vizsgálatok alapján”, Marketing \& Menedzsment, 52(2), 69-84

Totth G. (2009), „Stratégiai kihívások a megváltozott gazdasági környezetben a minőségi pálinka hazai forgalmazásában". in Losoncz M., Solt K., Szigeti C. (szerk.), Kautz Gyula emlékkötet: Halálának 100. és születésének 180. évfordulója alkalmából, Győr, Széchenyi István Egyetem, 233-242

Totth G., Kovács I., Mezőné Oravecz T., Zarándné Vámosi K. (2017), „A fiatalok pálinkafogyasztási szokásai”. in Bányai E., Lányi B., Törőcsik M. (szerk.), Tükrözödés, társtudományok, trendek, fogyasztás: Egyesület a Marketing Oktatásért és kutatásért (EMOK) XXIII. országos konferencia: Tanulmánykötet, 230-238

Törőcsik M. (2007), Vásárlói magatartás, Budapest, Akadémiai Kiadó

Varian, H. L. (2010), Mikroökonómia középfokon, Budapest, Akadémia Kiadó, 36-145

Wittink, D. R., Vriens, M. and Burhenne, W. (1994), "Commercial use of conjoint analysis in Europe: results and critical reflections", International Journal of Research in Marketing, 11(1), 41-52 DOI: 10.1016/0737-6782(94)90043-4 
Mucha László, PhD hallgató

mucha.laszlo@phd.uni-szie.hu

Szent István Egyetem

Gazdálkodás és Szervezéstudományok Doktori Iskola

Oravecz Titanilla, tanársegéd

Oravecz.Titanilla@uni-bge.hu

Totth Gedeon CSc, föiskolai tanár

Totth.Gedeon@uni-bge.hu

Budapesti Gazdasági Egyetem

Külkereskedelmi Kar

Marketing Tanszék

\section{Analyzing the pálinka purchase aspects by conjoint analysis}

\section{THE AIMS OF THE PAPER}

The research focuses on the importance of the three product attributes of pálinka (price, origin, fruit), the usefulness of their levels, and the examination of the segments formed on the basis of these.

\section{METHODOLOGY}

For this purpose of the research we used conjoint analysis based on evaluation, where we analyzed the consumer evaluation of three different fruit types of homemade and in-store pálinka in three price levels in this survey, the sample of 626 people corresponds to the composition of the Hungarian population over 18 years of age (age group, gender, region).

\section{MOST IMPORTANT RESULTS}

In the case of the purchase of pálinka, the price most influenced the purchase decision, followed by the fruit used and then the origin. Due to the large price difference between homemade and in-store pálinka, the consumer also decides on the origin when choosing the price. The purpose of the purchase clearly determines the role of price, fruit and origin in the purchase. Consumer ethnocentrism, which prefers domestic products to foreign, did not affect the level of the utility of origin.

\section{RECOMMENDATIONS}

The regulatory environment and the preference for homemade pálinka causes a difficult position for producers of pálinka, that is why they need to understand the consumer decisions and conjoint analysis can simulate this shopping situation. When buying pálinka, consumers do not clearly prefer the cheaper product. Our study has shown that the cheaper price does not necessarily mean a higher preference in the purchase of pálinka, the consumer decision is more varied. Our research also confirmed the preference for homemade pálinka, which is also caused by the huge price difference between homemade and in-store pálinka. Because of this situation, the producers of in-store pálinka are forced to develop a new and effective marketing communication strategy. To focus on the target groups and the strengthening of gift shopping can increase the competitiveness of commercial pálinka manufacturers. We strongly recommend further researches to help identify consumers for who a higher price means more utility, have a good financial position, live in a city, and prestige is an important consideration when buying drink. For these studies, we consider conjoint analysis an appropriate solution.

Keywords: conjoint analysis, consumer ethnocentrism, pálinka, preferences 